This item was submitted to Loughborough's Research Repository by the author.

Items in Figshare are protected by copyright, with all rights reserved, unless otherwise indicated.

\title{
'Grisley “L” business': Re-valuing female masculinity and butch subjectivity in Tipping the Velvet and The Night Watch
}

PLEASE CITE THE PUBLISHED VERSION

https://doi.org/10.1057/978-1-137-50608-5_11

\section{PUBLISHER}

Palgrave Macmillan

\section{VERSION}

AM (Accepted Manuscript)

\section{PUBLISHER STATEMENT}

This work is made available according to the conditions of the Creative Commons Attribution-NonCommercialNoDerivatives 4.0 International (CC BY-NC-ND 4.0) licence. Full details of this licence are available at: https://creativecommons.org/licenses/by-nc-nd/4.0/

\section{LICENCE}

CC BY-NC-ND 4.0

\section{REPOSITORY RECORD}

O'Callaghan, Claire. 2019. "'grisley "L” Business': Re-valuing Female Masculinity and Butch Subjectivity in Tipping the Velvet and the Night Watch". figshare. https://hdl.handle.net/2134/33469. 


\section{'Grisley “L” business'?? Re-Valuing Female Masculinity and}

\section{Butch Subjectivity in Tipping the Velvet and The Night Watch}

\section{Claire O’Callaghan}

According to the lesbian cultural critic Emma Healey, the figure of the butch lesbian not only carries 'the weight of nearly one hundred years of stereotyping on her shoulders', but suffers homophobic ‘scorn and ridicule’ from heterosexist culture as well as ‘internalised lesbophobia’ within lesbian communities. ${ }^{2}$ As Gayle Rubin indicates, the term 'butch’ is ‘the lesbian vernacular for women who are more comfortable with masculine gender codes, styles or identities than with feminine ones' and 'encompasses a variety of ways of and motivations for using masculine gender codes and preferences'. ${ }^{3}$ Butchness exists, therefore, as Jack Halberstam points out, on a varied continuum of female masculinities that signify 'differently gendered bodies’ and female subjectivities. ${ }^{4}$

Boyish, masculine and/or butch women feature in nearly all of Sarah Waters’s novels. In Tipping the Velvet (1998), Nancy King’s foray into the world of music hall male impersonation and her investment in modes of female masculinity facilitate her discovery of lesbian desire and, as I will discuss later, are integral to her expression of gender and her sexual coming-of-age. Likewise, in Affinity (1999), domestic servant Ruth Vigers is able to pass as male spirit 'Peter Quick’ in part because of her “masculine” hands. The protagonist, Margaret Prior, believes that the 'bloated fingers and a swollen, vein-ridged wrist', visible in a wax hand cast at the spiritualist museum, affirms "Peter's" identity, thus exposing an essentialist belief in the equation of masculinity with maleness. ${ }^{5}$ Similarly, in The Night Watch (2006), butch ambulance drivers, Kay Langrish and Mickey Carmichael, spend much 
time reflecting on the gendered and sexual freedoms gained through the advent of the Second World War as well as the varied losses entailed by the post-war return to heteropatriarchal normalcy. Finally, in The Little Stranger (2009), 'natural spinster', Caroline Ayres, is criticised by the novel's somewhat sinister narrator, Dr Faraday, for being too masculine or rather, not womanly enough, something Helen Davies examines at length in her chapter in this collection. ${ }^{6}$ Faraday’s description of Caroline as 'noticeably plain' and 'over-tall [...] with thickish legs and ankles' has given rise to the suggestion that Caroline is a lesbian because she does not confirm to the stereotypical connotations of "woman" and "feminine" (p. 9). Although Waters does not explicitly identify her as a lesbian, Lucie Armitt has argued that Waters’s portrayal of Caroline affirms her as such although, for Armitt, Caroline 'negate[s] her [own] presence as a lesbian'. ${ }^{7}$ Armitt's view implies that perhaps Caroline is another of Waters's masculine lesbian subjects after all.

The notion that because Caroline is a masculine woman she must be a lesbian exemplifies the concerns of Halberstam (and others) that lesbian genders and sexualities continue to be conflated and stereotyped. While recognising that such misreadings are prevalent in heterosexist societies and cultures, this chapter is not concerned with instances of female masculinity that are misread as indicative of lesbianism; rather, it is specifically concerned with the feminist politics at play in Waters's portrayal of masculine women who do desire other women and are readily identified as lesbian. As Halberstam and Rubin have both argued, more nuanced understandings of female masculinity and its relationship to lesbianism are required and, as Sherrie Inness points out, female masculinity and butch subjectivity in particular have long been 'inadequately described, explained, and theorised'. ${ }^{8}$

Indeed, within the history of lesbian scholarship, female masculinity, butch subjectivity and butch-femme dynamics are among the most contested topics and modes of existence within feminisms, with disagreements largely focusing on the nature, function and 
place of masculine genders and roles within lesbian and feminist cultures. While scholars such as Rubin, Halberstam, Joan Nestle and Sally Munt among others readily agree (albeit in different ways) on the value of butch genders and sexualities in asserting alternative forms of womanhood to those offered by dominant heterosexist feminist theory and heteropatriarchy, scholars such as Sheila Jeffreys, Julia Penelope and Cherrie Moraga continue to perceive the invocation of masculinity in relation to the category "woman" - the very category on which feminism itself is predicated - as fundamentally problematic. ${ }^{9}$ For instance, echoing Monique Wittig's contention that lesbians are not women, Moraga, a scholar who primarily researches femme subjectivity, comments that, 'to be butch, to me, is not to be a woman'. ${ }^{10}$ Jeffreys, meanwhile, considers that butch subjectivity exists only as a tool of power and domination. She asks:

what are the advantages and disadvantages [of being] butch? An advantage must [be] the superior status. Amidst all the hatred directed at lesbians by the straight world, butch lesbians [are] able to feel superior to someone, the femme. ${ }^{11}$

The assumption underlying the views of such critics holds that any expressions of masculinity within female and/or feminist contexts only ever function to recreate patriarchy and patriarchal gender norms that have no place within feminism. As Healey notes, regrettably, such views expose 'a tendency in some feminist circles not to understand [female masculinity and] the butch [subject] in the context of their own time and society, but to blame and attack them from within a different context'. ${ }^{12}$

Yet the ousting of female masculinity from mainstream feminism and pockets of lesbian feminism has negative effects. One important consequence is that non-normative expressions of femininity and female masculinity associated with lesbianism tend to be culturally inscribed within queer politics and queer theory. But, while queer discourse and Judith Butler's theory of performativity in particular (of which more later) has had a profound 
effect on feminist discussions of gender and identity, it is not without its critics. While lesbian-feminist scholars challenge the heterocentrism of feminist theory, they also argue that by embracing a broad spectrum of gendered and sexual subjects queer theories negate the specificity of gender. ${ }^{13}$ The effect of this is to lose the political potency of gender categories to critique patriarchy. Shane Phelan suggests that because the queer covers the categories lesbian and gay, this 'usage does not problematize [lesbian] membership in queerness and signals a more utopian [...] stance than is associated with lesbian and gay' ${ }^{14}$ In other words, queer homogenises differences between subjects in opposition to heterosexuality. Further, as Susan Ardill and Sue O’Sullivan’s note, while ‘Gender play is all the rage [....] where is a feminist consciousness and challenge to gender divisions and inequalities?'. ${ }^{15}$

Amidst these debates, recent academic criticism has sought to redeem butch genders and sexualities by re-contextualising female masculinity as lived experiences, historical categories and modes of desire within a feminist framework. ${ }^{16}$ It is within this re-evaluative, context that I suggest Waters’s fictional representations of female masculinity are valuably constituted. Her writings intervene in such heated feminist debates by re-examining, reassessing, and re-privilege specifically lesbian investments in masculine aesthetics.

Accordingly, this chapter explores the diverse strategies that Waters employs to revalue female masculinity and butch subjectivity. Focusing on Tipping the Velvet and her recent neo-forties work, The Night Watch I propose that each text lauds female masculinity and exalts the much maligned figure of the butch lesbian. Beginning with Tipping the Velvet, I propose that Waters rejects the denigration of butch women by celebrating erotic variants of female masculinity and its connectivity to forms of lesbian desire and lesbian subjectivity. This portrayal values female masculinity in the face of dominant views by mainstream feminists and (some) lesbian-feminists alike, who view masculine women as traitors for capitulating to masculine stereotypes and rejecting their own femininity. Building on this, I 
then suggest that The Night Watch challenges prejudiced heterosexist and lesbian-feminist stereotypes of the butch lesbian that have contributed to her denigration. Here, Waters's sombre portrayal of butch subjectivity elicits greater understanding of the prejudice, negativity and challenges faced by masculine women.

\section{Eroticising Masculine Aesthetics in Tipping the Velvet}

It is, by now, readily agreed that Waters's portrayal of gender in Tipping the Velvet embodies the central tenets of queer theory, and specifically Butler's theories of gender performativity outlined in her seminal work, Gender Trouble: Feminism and the Subversion of Identity (1990). Invaluable readings of the novel in relation to Butlerian theory can be found in Sarah Gamble’s article on gender and authenticity, in Helen Davies’s monograph Gender and Ventriloquism in Victorian and Neo-Victorian Fiction (2012), and in Allison Neal's article that discusses both the novel and its television adaptation vis-à-vis queer discourse. ${ }^{17}$ Yet, as I have argued elsewhere, Waters's play with gender in Tipping the Velvet is more complex than appraisals of Butlerian ideas on the destabilisation of gender allow. ${ }^{18}$ She negotiates the value of queerness with the political signification of gender with which feminism is concerned. As Mandy Koolen points out, in Tipping the Velvet, Waters re-creates lesbian history (albeit a fictional one) by undertaking 'the important work of filling in gaps in the historical record by speculating about past experiences of same-sex desire that have been erased or neglected in many historical studies'. ${ }^{19}$ While Koolen does not discuss the significance of female masculinity and/or butchness within a feminist context, her conception is capacious enough to comfortably accommodate such a reading.

Ironically - given Koolen’s emphasis on the place of erasure within lesbian historiography - it was following the broadcast of Andrew Davies's adaptation of Tipping the Velvet (2002) that Waters commented that although she was delighted by the production, 
'Rachel Stirling’s Nancy Astley was not really the Nancy I had imagined’ as 'I had always thought of Nancy as [...] crucially - more butch' ${ }^{20}$ Waters's comment is striking because it emphasises how the BBC production accentuated Nancy's femininity at the expense of her masculinity. Moreover, it also reveals how, for Waters, Nancy's sense of self is informed by masculinity, in particular, a sense of boyishness.

As I have argued elsewhere, Tipping the Velvet exemplifies Martha Vicinus's contention that historically cross-dressing has had erotic appeal for lesbians because of the combined use of masculine and feminine imagery at play. ${ }^{21}$ During a television interview in 2008, Waters indicates that it is precisely the overlap of female masculinity, femininity and lesbian sexual imagery in nineteenth-century images of music hall male impersonators that provided the appeal for her appropriation of the period:

I was really interested in what sort of erotic charge male impersonation might have had for its viewers. I have got lots of pictures of male impersonators. They are all terribly dapper in their suits. They look like drag kings. They look like lesbians. At the same time [the Victorian era], male impersonation was absolutely at the heart of mainstream culture. I suspect that for some viewers it did have a lesbian charge to it. ${ }^{22}$ Waters's comment is significant because it situates female cross-dressing at the heart of mainstream (and heterosexist) Victorian society yet sets it as ripe imagery for lesbian reappropriation. In the novel, Nancy is unable to pinpoint why 'when [Kitty] stepped on stage at last, there would be that rush of gladness so swift and sharp that I would catch my breath to feel it, and grow faint'. ${ }^{23}$ But she is aware that it is the meeting of masculinity and femininity in Kitty's appearance that arouses her:

She was, as Tricky had billed her, a kind of perfect West-End swell [...] It was the hair, I think, which drew me most [...] the nape of her where the collar ended and the hairline began [...] her face was a perfect oval, and her eyes were large and dark at 
the lashes, and her lips were rosy and full. Her figure, too, was boy-like and slender. (pp. 12-13)

As Nancy’s words indicate, it is specifically because Kitty is ‘like a very pretty boy’ who couples a 'boy-like' aesthetic with a 'full', 'rosy' and 'rounded' figure that Nancy acknowledges her 'the most marvellous girl—I knew it at once!—that I had ever seen' (p. 13). Moreover, in the very first imagery of Kitty onstage, Waters uses the lesbian-feminist literary technique of cultural symbolism to foreground lesbianism. Kitty wears a 'rose in her lapel, and lavender gloves at her pocket' (p. 12). Roses are not only symbols of love, but lavender is also a colour associated with lesbianism. As such, the way in which Waters combines boyishness with lesbian desire resists Jeffreys's idea that masculinity and women are incompatible.

However, Kitty’s engagement with masculine aesthetics has its limits. Offstage, Kitty's investment in feminine modes of dress and self-expression situates her as a femme lesbian (although, importantly, Waters does not use such terms in the novel). Like the term “butch”, “femme” describes a 'sustained’ lesbian 'gender identity' in which femme subjects identify with feminine expressions of self. ${ }^{24}$ Kitty’s concealment of her sexuality suggests that she seeks to pass as a heterosexual woman. This is certainly the impression she gives Nancy both at the time of Nancy's discovery of her betrayal with theatrical manager, Walter Bliss, and later at the political rally in London in the closing chapters of the novel. Kitty’s need to pass arises from her fear of 'toms', a slang term deriving from the word 'Tommies'itself a likely derivative of 'tom boy'- all of which were mid-nineteenth-century terms for 'boyish, uncontrollable girls' and masculine women, 'who do [...] not care for the society of others than those of her own sex' ${ }^{25}$ For Kitty, being labelled a 'tom' is problematic because it associates lesbian desire with a butch-femme archetype and, as Phelan points out, we 'live in a world that is heterosexist and largely homophobic and those constraints continue to shape 
the lives of individuals of all sexual orientations, preferences and identifications' ${ }^{26}$ Phelan's point makes it all the more important that Waters shows Nancy to embrace a boyish aesthetic. In the novel, Kitty disassociates herself from the butch-femme inflection of lesbian desire by castigating other female impersonators who express same-sex intimacy more openly: 'They're not like us! They're not like us, at all!', she tells Nancy, 'They're toms [...] They make a - a career - out of kissing girls’ (p. 131). Significantly, the notion of being identified as a 'tom' comes back to haunt the women when they perform at the Deacon's Music Hall, as they are sneered and spat at by a jeering crowd who declare, 'You call them girls? Why, they're nothing but a couple of - a couple of toms!' (p. 140), an accusation Nancy notes 'Kitty had once whispered to me, flinching and shuddering as she said it' (p. 140). Such comments reveal how gendered and sexual norms are controlled by heteronormativity. In this way, Waters draws on expressions of female masculinity to demonstrate feminist concerns regarding the abjection of women by pointing to the "'Othering'” of those who do not adhere to female norms.

Nancy's investment in female masculinity and her understanding of her sexuality function differently, for Nancy is - in these early stages - emerging as a butch lesbian. Her first experience of wearing her onstage costume works to reveal her masculinity. Walter comments, 'there’s something queer about it' (p. 118). Likewise, the landlady of the theatrical lodgings, Mrs Dendy, reflects, ‘she looks like a boy. Which I know she is supposed to [...] but, if you follow me, she looks like a real boy’ (p. 118). While these quotes usefully work to reflect Butler's theory of performativity and particularly her idea that there are no original gender categories, Waters also emphasises that Nancy is merely 'like a real boy', rather than a real boy or, indeed, a girl who wants to be a boy. This is important as it reinforces the point that while Nancy goes on to identify with masculine aesthetics, she is does not want to be a man. 
Waters also demonstrates the eroticism of female masculinity through Nancy's relationship with wealthy Sapphist, Diana Lethaby, who tells Nancy that, “my dear, You have exactly what I'm after' (p. 233). Nancy is the latest in a portfolio of sexualised 'boys' in Diana's life, all of whom Diana fashions in dandy-esque aesthetics for her own sexual interests. Installed as Diana's 'tart' (p. 248), Nancy is informed that in return for sexual "services" she will profit in social and cultural terms from the privileges and values of Diana’s lifestyle:

My dear, I have said: you should have pleasure for your wages! You should live with me here, and enjoy my privileges. You should eat from my table, and ride in my brougham and wear the clothes I will pick out for you - and remove them too, when I should ask it. You should be what the sensational novels call kept! (p. 249)

Interestingly, this marks the beginning of Nancy’s make-over into 'the boy’ (p. 279). Diana provides Nancy with a wardrobe of suits and male clothing, jewels and accessories, and encourages Nancy to preen herself for Diana’s gaze and the gaze of her friends. Nancy notes that ‘to [...] all places [...] I went clad as a boy' (p. 279). While Nancy identifies with boyishness, Diana, like Kitty, identifies as a femme. Butch-femme subjectivities often tend to be analysed together and have frequently been denounced as anti-feminist practices. Jeffreys, for instance, suggests that butch aesthetics are a 'damaging effect of the promotion of roleplaying' in lesbian culture in which lesbians replicate heterosexual norms (whereby the butch partner assumes an active and masculine role similar to a heterosexual man and the femme subject adopts a passive and supportive feminine role as that of heterosexual woman). She states that, therefore, butch-femme dynamics are antithetical to feminism. ${ }^{27}$ Of course, such views create negative stereotypes of lesbianism and treat butch-femme lifestyles unsympathetically, denouncing butch and femme as 'pre-feminist repressive practices' ${ }^{28}$ 
Yet Waters's novels participate in discourses keen to dispel this myth and, in Tipping the Velvet, she does so by reversing the power dynamics between butch-femme subjects. Diana is a cruel figure who exploits Nancy as well as her own female house staff for her own ends. Nancy's relationship with Diana is fraught with tension because of the way in which Diana controls her. While Diana enables Nancy to express her lesbian desires, she also “possesses” her, keeping her enclosed in the ironically named Felicity Place and making her accompany her (like a pet) on visits. As such, the women's relationship is an uneasy balance of female agency and exploitation. Importantly, while this may be read as Waters offering a critique of femme subject, any such deduction belies the complexity of Waters's narrative. She is not critiquing femme subjects or those who engage in butch-femme dynamics; rather, Waters is critical of any subject who seeks to dominate and exploit another. Moreover, that Nancy becomes the subject of Diana's gaze subverts the idea that it is only ever femininity (or feminine subjects) who are the object of the gaze, thus valorising female masculinity as desirable.

It is precisely because of the abuse and exploitation in their relationship that Nancy leaves (or is expelled) from Felicity Place and subsequently finds happiness with socialist feminist, Florence Banner. Through Nancy and Florence Waters evokes (and re-visions) the figure of the New Woman, the fin-de-siècle phenomena whose "birth" was contemporaneous with first-wave feminism, socialism, decadence and scientific and medical discourse surrounding homosexual identities. ${ }^{29}$ In her campaign for political, social and sexual equality, the New Woman subverted gender and sexual patriarchal norms. But although her so-called political agenda 'speaks to cultural anxieties about the "masculinisation" of women' ${ }^{30}$, she was, as her name suggests, a woman, with feminist politics.

Importantly, one of the reformist behaviours of the New Woman was to mix "masculine” dress and "feminine” pursuits. ${ }^{31}$ Here Waters draws on this history to 
"anticipate" the figure of the butch lesbian and, in doing so, re-conceives of her origins in the nineteenth century. In the novel, in exchange for bed and free board in Florence's home, Nancy becomes a housekeeper to Florence and her brother, Ralph. But during this daytime “job”, Nancy combines butch aesthetics with a domestic role, a move that attacks Victorian patriarchy by highlighting both the constructed (and constricting) nature of "feminine" and "masculine” dress and, by implication, of “feminine” and "masculine” spheres. ${ }^{32}$ Noting that ‘wearing gentlemen's suits had magically unfitted [her] for girlishness', Nancy obtains a pair of moleskin trousers and leather boots and sets about undertaking her domestic duties in Quilter Street, boasting that she had 'become known as something of a trouser wearer in the district' (p. 404). She cuts her hair short and, as the hair falls to ground, comments, 'it was as if I had grown a pair of wings beneath my shoulder-blades, that the flesh had all grown over, and she [the hairdresser] was slicing free' (pp. 404-405). The detail that Waters provides of Nancy hair is almost fetishistic; it works to subvert both Victorian and contemporary modes of normative femininity and valorise alternative expressions of “woman”. Nancy also welcomes the changes in her physical appearance: 'it was as if my jaw had grown firmer, my brows heavier, my hips slimmer and my hands extra large' (p. 390) (which recalls Peter Quick's hands in Affinity), and comments that 'in wanting to wear trousers' she 'feels as though a young man must feel' (p. 411). These physical and aesthetic changes enable Nancy to recognise herself as butch sexual subject, and her words thus emphasis how, by the end of the novel, her "masculine” image throws into relief her butch sense of self.

Florence and the close lesbian community that surround her represent various incarnations of the New Woman as butch and femme subjects; they are a mixed class-based community of lesbians who embrace an assortment of gendered and sexual aesthetics and employment and economic circumstances. Florence’s friend, Annie Page, for instance, reflects the so-called "Mannish Lesbian”, a butch incarnation of the New Woman who 
enjoyed “"masculine” attire and "masculine” behaviour'. ${ }^{33}$ Annie works as a London sanitary inspector and she describes the significance of gaining so-called "men's work" as 'quite a triumph': 'men think women too delicate for this sort of work' (p. 369). That both Nancy and Annie express liberation through employment (both domestic and public) reflects the politics of socialist feminism at play in the final chapters of the text. Socialist feminism, a branch of feminism that emerged in the 1880s and found renewed currency in the 1970s, focuses on both the public and private spheres of women's lives. Socialist feminists argue that liberation can only be achieved by working to end both the economic and cultural sources of women's oppression.

Waters uses Nancy’s naivety towards diverse female groupings to establish a multitude of lesbian subjectivities within a feminist community. On a night out at a lesbian bar (which exports butch-femme bar culture of the 1940s and 1950s to the nineteenth century), Nancy says to Florence:

'I thought you said it would be all toms in here? There are blokes over there.'

'Blokes? Are you sure?' She turned to where I pointed [.] 'Blokes?' She said again.

'Those are not blokes! Nancy, how could you think it?'

I blinked, and looked again. I began to see... They were not men, but girls; they were girls - and they were rather like myself...

I swallowed. I said, 'Do they live as men, those girls?’ [...]

'Some do, I believe. Most dress as they please, and live as others care to find them' $[\ldots]$

'To think, [...] I might have worn my moleskins, after all...'. (pp. 416-417) Here, Waters celebrates how female masculinity (and femininity) can signal lesbian genders and how they can be erotic and enable agency. As Nancy notes, 'the thought [of] so many girls that she could put them into categories, like breeds of fish - was wonderfully and 
astonishing and stirring' (p. 436). In this way, Waters celebrates the breadth and diversity of female masculinity and its usefulness for (some) lesbians. That Nancy finds personal and emotional happiness with Florence endorses Waters's view that female masculinity is not only a capacious and erotic identity category for lesbians, but one capable of encompassing a diverse range lesbian gendered and sexual subjectivities.

\section{'She's such a bloody gentleman' 34 - The Night Watch}

Set in London during the war-torn 1940s, The Night Watch unfolds via a backward chronology (from 1947 through 1944 to 1941), the stories of four characters all of whom have survived the horrors of the Blitz but who remain, post-war, haunted by personal traumas. In the aftermath of the war, butch lesbian, Kay Langrish, continues to endure the painful loss of her beloved girlfriend, Helen Giniver, following Helen’s sexual betrayal during the war. Helen, a closeted lesbian, is caught in a volatile relationship with detective novelist, Julia Standing (also Kay’s ex-lover) with whom she cheated on Kay in 1944. Meanwhile, disillusioned 'glamour girl' Vivien (Viv) Pearce, remains stuck in a soured, illicit affair with married soldier, Reggie, and struggles to overcome the horrors associated with her wartime romance, namely, a backstreet abortion that left her grievously injured, and during which Reggie abandoned her (p. 244). Finally, Viv’s younger brother, former prison inmate, Duncan, is tormented both by the tragedy of his past - a failed suicide pact with his close friend, conscientious objector, Alec, for which Duncan feels responsible - and his inability to adjust to life outside of Wormwood Scrubs in peacetime.

It is through her portrayal of Kay, however, that Waters focuses on butch subjectivity. ${ }^{35}$ Notably, echoing her concern regarding the portrayal of Nancy in the adaptation of Tipping the Velvet, Waters has expressed similar views regarding the portrayal of Kay in the recent BBC production of The Night Watch (2012). Although she 'liked [the 
adaptation] very much', she noted that 'television isn’t great at showing butch characters and Kay is an example of this - I wrote her as a butch woman. Anna Maxwell Martin [who plays Kay] is a lot daintier than how Kay was meant to be'. ${ }^{36}$ That masculine women are obscured in the adaptations of Waters's novels demonstrates how representations of lesbianism in modern culture continue to be "normalised" via the femme body as well as highlights the continued currency of Terry Castle’s famous invocation of the 'apparitional' lesbian. ${ }^{37}$ The feminisation of Waters's masculine subjects for mainstream culture demonstrates Castle’s view that the lesbian (especially the butch lesbian) is, all too often, forced to occupy 'a recessive, indeterminate, misted-over space' ${ }^{38}$

In the novel, Waters critiques heterosexist and pejorative lesbian-feminist attitudes towards masculine women, and through Kay she examines female masculinity in relation to what Ann Cvetkovich describes as lesbian public cultures. ${ }^{39}$ Kay exemplifies social and cultural alienation from the stigma of lesbian sexuality; she represents the complexities of being an "out" butch woman in the 1940s period, showing how the adoption of male attire as a lesbian aesthetic agitates heterosociality. In a television interview, Waters notes the significance of the 1940s and particularly the war to lesbians. She states that the war was 'very exciting' for lesbians because 'it was like being given a license to be butch, to pull on some trousers, cut your hair, and drive a truck' ${ }^{40}$ The 'licence' that Waters speaks of is significant given that it was only at the end of the 1920s that Radclyffe Hall, through The Well of Loneliness (1928), helped inaugurate the figure of the mythic mannish lesbian, the invert - 'a man so trapped in a woman's body that she would dress like a man, think like a man, and have sex like a man (i.e. with a woman)' ${ }^{41}$ Both Kay and Mickey are archetypal configurations of the butch lesbian. Kay’s dress and masculine behaviours underline her identification with masculine sensibilities. The opening pages, which include a lengthy description of Kay's wardrobe and dressing routine, reinforce the importance of such 
aesthetics to her. Although her home is ‘nothing to her but a place in which to sleep' and thus, unlike Nancy, she rejects domesticity, the third-person narrative voice observes that 'her clothes, at least, were very neat', comprising ‘tailored slacks' and 'men’s shoes’ (p. 5). Kay and Mickey also point to the opportunities created by the war for butch women in particular. Their employment in the London Auxiliary Ambulance Service exemplifies the changing dress code that broke with conventions of femininity (uniforms and trousers) (pp. 257-259). Postwar, Mickey notes that she wants to continue working in such “men's” roles and that is why she works in a petrol garage: 'she was only at the garage, really, because it was one of the few places a woman could work and wear trousers' (p. 104). However, Waters also affirms that Kay and Mickey are women. Kay may opt for ‘tailored slacks’ and men’s shoes, but she also wears 'a soft white collar she could leave open at the throat, as a woman might' so that 'if anyone gazed properly into her face', they would identify her as a woman (p.5).

However, it is through the lesbian triangle between Kay, Julia and Helen that Waters challenges what Healy names 'lesbophobia’ towards butch women within lesbian communities, whereby butch women are scapegoated as traitors to feminism. ${ }^{42}$ In 1941 , Kay was in a relationship with Julia, a relationship that Kay characterises as 'a misaffection' (p. 368). Julia had loved Kay far more than Kay had felt for her, and Kay subsequently left Julia for Helen, believing that this new relationship was better suited, or in Kay’s words ‘a thing of wonder’ (p. 312). However, Helen feels stifled by Kay’s affection and lusts after Julia, erroneously believing that the 'misaffection' in Julia and Kay's relationship had been the other way around - that Kay had been in love with Julia, but Julia had not returned Kay’s affections equally (p. 368). This makes Helen lust after Julia all the more (p. 351), and Julia rather cruelly cultivates her romance with Helen, at least initially, in order to understand why Kay left her: 'to get the measure of you, something like that' (p. 367). Helen and Julia's conversations re-play criticisms of the butch lesbian. Both women castigate Kay for her 
idealism and her investment in heteronormative configurations of desire. Commenting on her relationship with Kay, Helen states that she feels 'like a child' (p. 315) and 'trapped' (p. 354) by Kay’s displays of affection. Julia points out that 'Kay’s a great sentimentalist' and she emphasises this in her grudging account of the way Kay described meeting Helen 'like something from a picture' (p. 368):

Kay told me all about it - about how she found you, and so on. She put it that way, you see: that she found you. She said how frightened it made her, when she thought of how nearly you might have been lost. She described touching your face [...] But then, as I say, Kay’s a sentimentalist. She remembers it as though it were a touch of fate to it, a touch of kismet. (p. 369)

As Julia implies, Kay constructs her relationship with Helen in terms of a utopian romance, a notion which emphasises Phelan’s point (quoted earlier) about the 'utopian stance' associated with lesbian and gay politics that queer theory negates. ${ }^{43}$ Helen and Julia reproach Kay for this and discuss their perception that Kay simply wants a 'wife' (p. 353). Helen reveals her discomfort of how Kay is always 'taking such care of me', a point that Julia believes is because of Kay's insistence on heterosexual role models: ‘Kay wants a wife. She always has. One must be the wife with Kay, or nothing.' (p. 353). Indeed, together, they denounce Kay’s 'gentlemanly' behaviour: 'She’s such a bloody gentleman. She’s more of a gentleman that any real man I ever knew’ (p. 425). To them, Kay’s “expectation” of butch-femme relationships are problematic because they reinforce heterosexual ideals in which the women can only function as the subordinated role. They perceive her affections as stifling because it limits their sense of agency and, above all, they believe that Kay’s "gentlemanly” behaviours indicate that she wants to be a man.

However, The Night Watch goes on to challenge such damning views of butch subjectivity in a number of ways. Because the women's stories unfold in reverse chronology, 
the reader first meets Kay as a traumatised figure in the post war moment; she is a woman struggling within a heterosexist society in which being a butch woman is tough (as the discussion of lesbian public cultures revealed) and who has lost her lover in a cruel manner. Significantly, in her discussion of butch subjectivity and trauma, Cvetkovich describes as an unwritten code of butchhood; historically butch lesbians have been stereotypically conceived of as emotionally (if not sexually) untouchable because a butch's 'masculinity depends on and is defined by her refusal to be made emotionally vulnerable or to display feeling publically or openly’ ${ }^{44}$ Through Kay, Waters complicates such views. Indeed, from the outset, she presents the very opposite. Still emotionally raw from losing Helen, in 1947, Kay reveals her torment to Mickey:

'Look at me, Mickey!’ she said. 'Look at the creature I’ve become! Did we really do those things we did? - you and I, when the war was on? [...] We carried stretchers, for God's sake! I remember lifting' - she spread her hands - 'I remember lifting the torso of a child...What the hell happened to me, Mickey? (p. 108)

Not accepting that Kay’s anguish is solely related to the trauma of war, Mickey responds: 'You know what happened' (p. 108); her words imply that Kay is not revealing the full reason for her pain:

Kay sat back and turned away, in disgust at herself. 'It's not more than happened to thousands of us. Who didn't lose someone, or something? I could walk on any street in London, stretch out my arm, touch a woman or a man who lost a lover, a child, a friend. But I - I can’t get over it, Mickey. I can’t get over it.' (p. 108) Kay's use of the word 'disgust' here captures something of the unwritten code that Cvetkovich speaks of. Her words reveal how her personal grief and loss connects with the politics of war and, in turn, the political impacts the personal. But here, by focusing on Kay’s emotions, Waters highlights the intimate and very personal nature of the politics of loss. By 
granting Kay the power to be emotionally expressive and making the reader privy to her heartache, Waters highlights the emotional vulnerability of the butch lesbian and invests her with dignity and feeling.

Secondly, from the outset, Waters portrays Kay not as a masculine woman aping heterosexual rules who dominates her femme lover (as scholars like Jeffreys believe and Helen implies). Rather, she presents Kay as a woman deeply in love with her partner. It is the depths of her passion for Helen that lead Kay to constitute their love in utopian terms and to recreate a somewhat Hollywoodised romance. Kay demonstrates Nestle’s assertion in the mid-twentieth century that 'a butch lesbian wearing men’s clothing [...] was not a man wearing men's clothes; she was a woman who created an original style to signal to other women what she was capable of doing, taking erotic responsibility' ${ }^{45}$ Interestingly, Cvetkovich reflects that the butch’s 'eagerness to attend another's desires' could actually be considered feminine as opposed to masculine. ${ }^{46}$ The gallantry complex that Helen and Julia speak of in which they perceive Kay’s masculinity as perilously equated with heroism and Helen's femininity as there to be saved and protected (p. 353) is not so much a reflection of normative gender ideals, but an investment in an intense and protective form of desire (that ultimately leads to her downfall). Indeed, Kay relays her idealism towards Helen by calling her as a 'glamour girl' (a term that Reggie also calls Vivien), comparing her to 'Greta Garbo in Grand Hotel' (p. 312). The term 'glamour girl' equates femininity with heteronormative stereotypes of women from the period in which the ideology of "beauty as duty" reinforced heteronormative ideals of gender, and the repetition between Kay and Reggie's use of the phrase undermines the notion that Kay is attempting to feminise Helen in line with heterosexual ideals. Indeed, because Reggie and Viv's heterosexual relationship - the one that (on the surface, at least) is acceptable - is empty and contains none of the love that Kay displays, Waters re-values and reinforces Kay's ardent love for Helen, and in doing so exalts 
the figure of the butch lesbian. Moreover, when speaking about Helen to Mickey, Kay states that 'this filthy war's knocked all the glamour out of life for women like her' but it is 'all right for' butches like them: 'we can just kick about in the muck and pretty well like it-' (pp. 254-255). While this may be read as reflecting a stereotypical difference between conceptions of masculinity and femininity, it shows how Kay seeks to preserve Helen from the horrors of war by making their life 'charming' and 'romantic' (p. 324). Finally, Kay does comment that 'it was one of the great tragedies of her life, that she couldn't be like a man to Helen - make her a wife, give her children’ (p. 326). Recalling Mrs Dendy’s use of the word 'like’ in Tipping the Velvet, again, the word 'like' here confirms that Kay does not want to be a man but rather, attain the rights and powers that men have open to them. It also highlights the limited options available to homosexual couples in the 1940s (notably undergoing significant change at the moment in which Waters was writing the book), rather than a desire to be heterosexual or of another sex.

Helen and Julia's affair functions (troublingly) as a form of punishment to Kay for her apparent investment in heterosexual idealism. However, Waters's representation of their developing romance serves only to align the reader’s sympathies with Kay, the betrayed lover, because the novel's reverse chronological structure creates an affective discourse surrounding Kay. Through the shifting narrative pattern, Waters juxtaposes the actions and stories of each character side-by-side to construct a compassionate portrayal of the butch woman. Through the 1944 section of the novel, for instance, the development of Julia and Helen’s friendship behind Kay’s back and Julia’s cultivation of Helen’s desire and knowing destruction of Kay’s relationship with Helen (p. 369, pp. 374-375) is paralleled by lengthy scenes of Kay's caring disposition, specifically her work on the night watch as an ambulance driver. During these scenes Kay exemplifies Munt’s celebration of the 'lesbian heroic'. ${ }^{47}$ Munt argues that the 'lesbian hero' is a figure reflecting 'a cultural strategy that evangelizes 
lesbian life. Heroes offer a myth of the self in movement, change and process [...] a radical myth [...] an icon of struggle'. ${ }^{48}$ Munt suggests that figures that claim a lesbian identity demonstrate 'a heroic act' when 'being lesbian' is a counter ideology to heteropatriarchy; it is 'a heroic performance for all who inhabit an intransigently homophobic culture’ ${ }^{49}$ Kay’s heroism manifests precisely through her so-called gentlemanly behaviours (after all, she does rescue Helen) and also through her employment, but such acts are not exclusively reserved for women. Kay is repeatedly in trouble for heroic wartime "stunts" on her night watch shift. Partridge, her station commander, derides her for regularly stopping on the return legs of her ambulance call-outs in which she helps to put out street fires and attend numerous victims of the night-time bombings that she comes across: 'You know the procedure. I'm warning you. You'll do this sort of thing once too often' (p. 208). Although Partridge's point is that Kay is flouting procedure, such actions demonstrate Kay’s humanitarian nature, her desire to help and support "the cause”, and above all, her bravery. Kay also takes on extra shift work to support her fellow colleagues. She does an additional “mortuary run”, for example, in order that O’Neill, a seventeen year-old women who had recently joined the corps, does not have to face the horrors of collecting the body parts of a family blown apart by an incendiary (p. 211). Kay tells her: 'you'll see enough awful things in this job, that's all, without being made to see them when you don’t have to' (p. 211).

Yet more specifically, this structure creates empathy with Kay because the scene during which Julia and Helen have sex (the only time that they are shown having sex in fact) is juxtaposed by Kay’s particularly touching interactions with Viv on the night of her abortion. It is immediately following her act of kindness towards Viv that Kay is shocked to discover that her own home (in Rathbone Place), where she believes Helen is, has been bombed. The reader is aware that Helen is safe and, of course, that she has been cheating on Kay with Julia. Waters constructs in painstaking detail the ordeal that leads to Kay’s trauma, forcing 
the reader to experience Kay's distress. When Kay arrives at the scene to find that she 'recognised nothing', the reader faces Kay’s harrowing belief that Helen is dead; the narrator summarises that 'the knowledge undid her' (p. 454). However, this is followed just a page later by the revelation that Helen is in fact alive. The passage reads:

She covered her eyes. She didn't get up. Helen had to come to her and help her to her feet. And even then she wouldn't take her hands from her face; she let Helen embrace her awkwardly, and she laid her brow against Helen's shoulder and wept like a child into her hair. She didn’t feel pleasure or relief. She felt only, still, a mixture of pain and fear so sharp, she thought it would kill her. (p. 454) If, as Cvetovich comments, butches do not publically express emotion, then here Waters subverts this “rule” to articulate Kay’s torment and express the depths of her feelings for Helen. Yet the reader's emotional investment is compromised because we already know the fate of their relationship and, at that moment in the text, are privy to knowledge that Kay is not. The scene concludes with Kay thanking Julia for returning Helen to her: 'Julia. Oh, Julia! Thank God! I thought I’d lost her’ (p. 454). Kay’s words are a tragic irony because she has already, in effect, lost Helen. Moreover, it is especially cruel because the 1941 scene that follows depicts how Kay first met Helen, when she rescues her after a bomb raid. This scene, which ends the novel, is doubly poignant as Waters forces the reader to engage with the optimism that Kay feels on meeting Helen in which, as Kay states, she could not 'believe that something so fresh and so unmarked could have emerged from so much chaos’ (p. 503). It is a cruel optimism, however. Through this affective history, then, Waters creates a redemptive reading of the butch woman, showing her investment (in the pre-Stonewall era) in normative understandings of gender and sexuality as a mode of passion and desire that reflects a deeply held public commitment to a lesbian lifestyle. 


\section{Conclusion: Valuing Masculine Women}

In conclusion, each of Waters's texts present engagements with modes of female masculinity that challenge disparaging views of butch women and provide rich insights into the ontologies, aesthetics, politics and histories of female masculinity and butch subjectivity. In both novels Waters use intra-lesbian cultural dynamics to re-assess negative feminist discourse concerning butchness within lesbian-feminist politics, and specifically the maligned stereotypes attributed to butch masculinity. While examining the conceptions and misconceptions of female masculinity and lesbian gender, Waters also lauds the sexual, intimate and erotic possibilities of alternative expressions of female gender, and specifically those that encompass masculine aesthetics. At the same time, however, her writings do not homogenise lesbian genders; she offers varied expressions of lesbian subjects and leaves open the idea that there are many different ways to be lesbian or for women to desire other women.

Importantly, while Tipping the Velvet and The Night Watch undoubtedly reflect queer theoretical ideas, they also demonstrate Waters’s commitment to feminist identities, categories and politics. These novels exemplify Rubin’s point that for lesbians, 'categories are important' because without them 'we cannot organize a social life, a political movement, or our individual identities and desires'. ${ }^{50}$ Waters's lesbian-feminist politics reflect Rubin's sentiment that 'instead of fighting for immaculate classifications and impenetrable boundaries, let us strive to maintain a community that understands diversity as a gift, sees anomalies as precious, and treats all basic principles with a hefty dose of scepticism' ${ }^{51}$

\section{Notes}

\footnotetext{
${ }^{1}$ Sarah Waters, The Night Watch (London: Virago, 2006), p. 274. Hereafter page numbers appear parenthetically in the text.
} 
2 Emma Healey, Lesbian Sex Wars (London: Virago, 1996), p. 42.

${ }^{3}$ Gayle Rubin, 'Of Catamites and Kings: Reflections on Butch, Genders, and Boudaries’, The Persistent Desire: A Femme-Butch Reader, ed. by. Joan Nestle (Boston, Mass: Alyson Publications, Inc., 1992), pp. 466 - 482, (p. 467).

${ }^{4}$ Jack (formerly Judith) Halberstam, Female Masculinity (Durham and London: Duke University Press, 1998), p. 8.

${ }^{5}$ Sarah Waters, Affinity (London: Virago, 1999), p. 130. Hereafter page numbers appear parenthetically in the text.

${ }^{6}$ Sarah Waters, The Little Stranger (London: Virago, 2009), p. 9. Hereafter page numbers appear parenthetically in the text.

${ }^{7}$ Lucie Armitt, 'Garden Paths and Blind Spots', New Welsh Review, (2009) 85, pp. 28-35, (p. 34).

${ }^{8}$ Sherrie A. Innes and Michelle Lloyd, “"G.I Joes in Barbie Land”: Recontextualising Butch in Twentieth-Century Culture', NWSA Journal, 7:3 (1995), 1-23, (p. 1-2). In her paper, Innes calls for a radical reorientation of lesbian and feminist scholarship to revalue what she deems prevailing misconceptions of the relationship between lesbian genders and desires.

${ }^{9}$ See: Sheila Jeffreys, 'Butch and Femme: Now and Then', Not Just a Passing Phrase: Reclaiming Lesbians in History, 1840-1945, ed. by. Lesbian History Group (London: The Women’s Press, 1989), pp. 158-187, and Julia Penelope, ‘Whose Past Are We Reclaiming’, Common Lives, Lesbian Lives, 9 (1983): 18.

${ }^{10}$ Amber Hollibaugh and Cherrie Moraga, 'What We're Rollin Around in Bed With: Sexual Silences in Feminism', Powers of Desire: The Politics of Sexuality, ed. by Ann Snitow, Christine Stansell and Sharon Thompson (New York: Monthly Review, 1983), pp. 394-405, (p. 400).

${ }^{11}$ Jeffreys, Not Just A Passing Phase, p. 169. 
${ }^{12}$ Healey, Lesbian Sex Wars, p. 43.

${ }^{13}$ Sheila Jeffreys, The Lesbian Heresy (London: The Women’s Group, 1993), p. 176; Paulina Palmer, Contemporary Lesbian Writing: Dreams, Desire and Difference (Buckingham: Open University Press, 1993), p. 29; Bonnie Zimmerman, “'Confessions’ of a Lesbian Feminist’, Cross Purposes: Lesbians, Feminists, and the Limits of Alliance, ed. by Dana Heller (Bloomington: Indiana University Press, 1997), pp. 157-168, (p. 166); Suzanne Danuta Walters, 'From Here to Queer: Radical Feminism, Postmodernism, and the Lesbian Menace (Or, Why Can’t A Woman Be More Like a Fag?’, Signs: Journal of Women in Culture and Society, 21:4 (1996), 830-863.

${ }^{14}$ Shane Phelan, 'The Shape of Queer', Women and Politics, 18.2 (1997), 55-73, (p. 58).

${ }^{15}$ Susan Ardill and Sue O'Sullivan, 'Butch/Femme Obsessions', Feminist Review, 34: (1990), 79-85 (p. 79).

${ }^{16}$ See Sherrie Innes’s work.

${ }^{17}$ See: Sarah Gamble, “"You cannot impersonate what you are”: Questions of Authencity in the Neo-Victorian Novel', Lit: Literature, Interpretation, Theory, 20:1(2009), 126-140, Helen Davies, Gender and Ventriloquism in Victorian and Neo-Victorian Fiction: Passionate Puppets (Basingstoke: Palgrave Macmillan, 2012), and Alison Neal, ‘(Neo)-Victorian Impersonations: Vesta Tilley and Tipping the Velvet', Neo-Victorian Studies, 4:1 (2011), 5576.

18 See: Claire O’Callaghan. “'Lesbo Victorian Romp”: Women, Sex and Pleasure in Sarah Waters's Tipping the Velvet', Sexualities and Contemporary Fiction, ed. by Joel Gwynne and Angelia Poon (Amherst, NY: Cambria Press, 2012), pp. 61-80, 'The Equivocal Symbolism of Pearls in the Novels of Sarah Waters', Contemporary Women’s Writing, 6:1 (2012), 20-37, and 'The Negotiation of Feminisms and Queer Theories in the Novels of Sarah Waters' (Unpublished Doctoral Thesis, University of Leicester, 2013). 
${ }^{19}$ Mandy Koolen, 'Historical Fiction and the Revaluing of Historical Continuity in Sarah Waters’s Tipping the Velvet', Contemporary Literature, 51.2 (2010), 371-397, (p. 373). ${ }^{20}$ Sarah Waters, 'Desire, betrayal, and 'lesbo Victorian romps: Sarah Waters Q\&A', The Guardian, 5 November 2002, <http://www.theguardian.com/books/2002/nov/05/fiction>, (accessed 20 April 2014). Web.

${ }^{21}$ Martha Vicinus, Intimate Friends: Women Who Loved Women: 1778-1928 (London and Chicago: University of Chicago Press, 2004) p. 184. See: O’Callaghan, “"Lesbo Victorian Romp”, p. 65.

${ }^{22}$ Sarah Waters, Sarah Waters: The South Bank Show. Interview by Melvyn Bragg. ITV Productions. Dir. Gillian Greenwood. 8 June 2008. Television. 10:00 minutes.

${ }^{23}$ Sarah Waters, Tipping the Velvet (London: Virago, 1998), p. 21. Hereafter page numbers appear parenthetically in the text.

${ }^{24}$ Laura Harris and Elizabeth Crocker, Femme: Feminists, Lesbians and Bad Girls (London: Routledge, 1997), p. 1.

${ }^{25}$ Emma Donoghue, Passions Between Women: British Lesbian Culture 1668-1801 (London: Scarlet Press, 1993), p. 5.

${ }^{26}$ Phelan, ‘The Shape of Queer', p. 60. Of course, the terms “butch” and “femme” are twentieth century concepts although other models of lesbian identification were available. For more on these see Emma Donoghue's Passions Between Women (previously cited) and Lillian Faderman's Surpassing the Love of Men: Romantic Friendship and Love Between Women from the Renaissance to the Present (New York: Harper Collins, 1998).

${ }^{27}$ Sheila Jeffreys, Unpacking Queer Politics: A Lesbian-Feminist Perspective, (Cambridge: Polity Press, 2003), pp. 126-127.

${ }^{28}$ Harris and Crocker, Femme Feminists, p. 2. 
${ }^{29}$ Sally Ledger, The New Woman: Fiction and Feminism at the Fin de Siècle (Manchester: Manchester University Press, 1997), p. 1.

${ }^{30}$ Cheryl Wilson, 'From the Drawing Room to the Stage: Performing Sexuality in Sarah Waters’s Tipping the Velvet', Women’s Studies, 35:3 (2006), 285-305, (p. 294).

${ }^{31}$ Ann Heilmann, '(Un)Masking Desire: Cross-Dressing and the Crisis of Gender in New Woman Fiction', Journal of Victorian Culture, 5 (2000), 83-111, (p. 86).

${ }^{32}$ Heilmann, ‘(Un)Masking Desire’, pp. 87-88.

33 Susan C. Shapiro, 'The Mannish New Woman: Punch and Its Precursors', The Review of English Studies, 42 (1991), 510-522, (p. 512).

${ }^{34}$ Sarah Waters, The Night Watch (London: Virago. 2006), p. 425. Hereafter cited parenthetically.

${ }^{35}$ In her reading of Kay, Rachel Wood suggests that 'Kay’s reading as butch is never assured’ (p. 306). My reading not only differs from Wood's with regards to Kay’s butch identity, but also in the fact that Wood is hesitant to utilise - or to suggest that Waters endorses - identity categories at all (such as “woman” and “lesbian”) because, in her view, they are 'loaded with contemporary meanings' (p. 306). For me, this is the very point of Waters's use of historical fiction; it enables her to export contemporary discourse, rhetoric and debates to historical settings in the service of gendered and sexual narratives. Wood's paper, “Walking and Watching” in Queer London: Sarah Waters’ Tipping the Velvet and The Night Watch' can be found in the Journal of Lesbian Studies 17:3-4 (2013), 305-316.

${ }^{36}$ Milly Shaw, ““Television isn’t great at showing butch characters” - exclusive interview with Sarah Waters', Lesbilicious, 30 June 2011, <http://www.lesbilicious.co.uk/televisionisnt-great-at-showing-butch-characters-exclusive-interview-with-sarah-waters/>, (accessed 20 May 2014). Web. 
${ }^{37}$ Terry Castle, The Apparitional Lesbian: Female Homosexuality and Modern Culture (New York: Columbia University Press, 1993).

${ }^{38}$ Castle, The Apparitional Lesbian, p. 2 and 31.

${ }^{39}$ Ann Cvetkovich, An Archive of Feelings: Trauma, Sexuality, and Lesbian Public Cultures (Durham and London: Duke University Press, 2003).

${ }^{40}$ Sarah Waters, Sarah Waters: The South Bank Show, 55:52 minutes.

${ }^{41}$ Healey, Lesbian Sex Wars, p.42.

${ }^{42}$ Healey, Lesbian Sex Wars, p.42.

${ }^{43}$ Phelan, 'The Shape of Queer', p. 58.

${ }^{44}$ Cvetkovich, An Archive of Feeling, p. 67.

${ }^{45}$ Nestle, The Persistent Desire, p. 141.

${ }^{46}$ Cvetkovich, An Archive of Feelings, p. 67.

${ }^{47}$ Sally Munt, Heroic Desire: Lesbian Identity and Cultural Space (London: Cassell, 1998), p. 1.

${ }^{48}$ Munt, Heroic Desire, p. 2.

${ }^{49}$ Munt, Heroic Desire, p. 3.

${ }^{50}$ Rubin, ‘Of Catamites’, p. 477.

${ }^{51}$ Rubin, 'Of Catamites’, p. 478. 